\title{
Water Quality Assessment of a Trout Farming Effluent, Bocaina, Brazil
}

\author{
Bernardo Pinto Caramel1, Munique de Almeida Bispo Moraes, Clovis Ferreira do Carmo', \\ André Martins Vaz-dos-Santos' ${ }^{2}$, Yara Aiko Tabata ${ }^{3}$, João Alexandre Saviolo Osti ${ }^{1}$, \\ Carlos Massatoshi Ishikawa ${ }^{1}$, Marcos Aureliano Silva Cerqueira ${ }^{1}$, \\ Cacilda Thais Janson Mercante ${ }^{1}$ \\ ${ }^{1}$ Water Resources Center, Fisheries Institute, São Paulo, Brazil \\ ${ }^{2}$ Federal University of Paraná, Curitiba, Brazil \\ ${ }^{3}$ Experimental Station of Salmon, São Paulo, Brazil \\ Email: cthais@pesca.sp.gov.br
}

Received 27 May 2014; revised 21 June 2014; accepted 12 July 2014

Copyright (C) 2014 by authors and Scientific Research Publishing Inc.

This work is licensed under the Creative Commons Attribution International License (CC BY). http://creativecommons.org/licenses/by/4.0/

(c) (i) Open Access

\section{Abstract}

The concern in mitigating the negative impact generated by the discharge of nutrients in the receiving water body is a challenge for the sustainable development of Brazilian fish farms. Thus, the purpose of this study was to evaluate the water quality and environmental impact caused by trout farming system effluent with focus on discharge of phosphorus. Sampling was performed on a weekly basis in triplicate from September to November 2010. Sample sites were distributed according to the water flow: upstream from trout farming system, water supply, effluent, artificial wetland, mixing zone and downstream (60 m from effluent). In the field, $\mathrm{pH}$, conductivity, dissolved oxygen, water temperature and turbidity were measured. In laboratory, nitrogen and phosphorus series, chlorophyll $a$, total solids suspended and their organic and inorganic fractions were analyzed. For the good growth of trout in production system, the abiotic factors described in the water quality monitoring demonstrated acceptable values. Environmentally, after passing through the production system and artificial wetland, there was an increase in concentrations of total phosphorus, total nitrogen, orthophosphate, ammonium, chlorophyll $a$, total solids suspended and their organic and inorganic fractions $(P<0.05)$. These results are related with the quality of feed, feeding management and the inefficiency of the artificial wetland. Therefore, it is necessary to use best quality feed to meet the nutritional requirements of trout, maintaining an optimal feed conversion and reducing pollution generated by effluent.

\section{Keywords}

Management, Feeding, Water Flow, Discharge, Phosphorus, Pollution 


\section{Introduction}

Although Brazil is situated in a region of tropical and subtropical climates, trout has been adapted well in the mountainous regions where temperatures are lower, close to $22^{\circ} \mathrm{C}$ in the hottest month and for at least four months is greater than $10^{\circ} \mathrm{C}$ [1]. In these areas, the rivers are small, with an insufficient flow for the deployment of large trout farming systems [2]. In Brazil from 2008 to 2010, there was an increase of $40 \%$ in the trout production. It was produced about 3660 tons in 2008, 4381 tons in 2009 and 5122 tons in 2010 [3]. Fish farming, as other animal production, causes impact on the environment [4] and has a potential trend of freshwater eutrophication, due to excessive discharge of nutrients [5] [6]. The pollution is generated from the feed introduced into the farming system, directly by the dispersion of the feed not eaten and/or by the metabolic products excreted by fish [4] [7]. The feed produced in Brazil uses waste of fish, with low levels of protein and high ash contents. Depending on the characteristics of the raw material, the feed contains a large amount of mineral material from the bones and scales [8].

The effect of discharge of the effluent of the fish farming in the ecosystem is related to the concentration and characteristics of the pollutant and the assimilative capacity of the receiving water body [9]. This effect can vary according to the production system, management practices, and the type of supplied food [10] [11].

Studies that assess the level of pollution in the effluent and in the receiving water bodies are extremely important in order to propose appropriate measures to mitigate the impacts generated by trout farming. Several authors have focused on this theme [12] [13], that remains inedited in Brazil.

Currently, the biggest challenge of trout farming and other productions in freshwater ecosystems is to mitigate the impacts generated by the productive system in the environment. The purpose of this study was to evaluate the water quality and environmental impact caused by trout farming system effluent with focus on discharge of phosphorus.

\section{Material and Methods}

\subsection{Study Area and Fish Ponds Management}

This study was conducted in a trout farming system located in the National Park of Serra Bocaina, $35 \mathrm{~km}$ from the Bananal city, São Paulo State, in the Paraiba do Sul River Basin situated $1155 \mathrm{~m}$ above sea level at coordinates $22^{\circ} 50^{\prime} 03.92^{\prime \prime} \mathrm{S}$ and $44^{\circ} 25^{\prime} 46.33^{\prime \prime} \mathrm{W}$ (Figure 1 ).

The trout farming used raceways system (adapted) getting constant water flow with estimated average flow rate at $40 \mathrm{~L} / \mathrm{s}$, keeping the residence time around $1 \mathrm{~h} 46 \mathrm{~min}$ of the entire system. The masonry tanks were divided into three sectors (Figure 2) with 4 tanks each, total volume of $315 \mathrm{~m}^{3}$, with an average density 2.45 $\mathrm{Kg} / \mathrm{m}^{3}$ and production capacity estimated at $3.5 \mathrm{t} / \mathrm{year}$.

The initial stock was 50,000 individuals of rainbow trout (Oncorhynchus mykiss) at different stages of growth, consisting of fingerlings ( $2 \mathrm{~g}$ ), juveniles (20 - $140 \mathrm{~g}$ ) and adults (220 g), totaling $776 \mathrm{Kg}$ in the system. Production in intensive feeding regime used commercial extruded feed $36 \%-42 \%$ crude protein (CP), ranging from $1.5 \%$ to $6 \%$ of the fish biomass. The estimated fish biomass was calculated by sampling 100 individuals per tank, totaling 400 individuals per sector, and extrapolated to the whole system of production.

\subsection{Limnological Parameters}

Sampling was performed on a weekly basis in triplicate from September to November 2010 in six sites $(\mathrm{n}=234)$. The Figure 3 shows the distribution of the sampling sites in the production system.

In the field, with Multiprobe HORIBA U-22 model, were determined the variables $\mathrm{pH}$, conductivity (Cond), dissolved oxygen (DO), water temperature (T) and turbidity (Turb). The values of DO were transformed in percentage of oxygen saturation. In the laboratory, the concentrations of total phosphorus (TP) and total nitrogen (TN) were determined according to the method proposed by Valderrama [14]. The orthophosphate $\left(\mathrm{P}-\mathrm{PO}_{4}\right)$ followed the methodology described in Strickland and Parsons [15]. Ammonium (N-NH$)$, nitrite $\left(\mathrm{N}^{\left.-\mathrm{NO}_{2}\right)}\right.$ and nitrate $\left(\mathrm{N}-\mathrm{NO}_{3}\right)$ were measured according to the methods described in Apha et al. [16]. The concentrations of total suspended solids (TSS) and their organic and inorganic fractions were determined using the gravimetric method described in Teixeira et al. [17], with modifications based on Wetzel and Likens [18], who consider the maximum temperature of $60^{\circ} \mathrm{C}$ during $24 \mathrm{~h}$ to obtain the organic fraction. Glass fiber filters and Millipore AP-40 paper with porosity from $0.7 \mu \mathrm{m}$ to $1.4 \mu \mathrm{m}$ were used to retain particulate fraction [16]. The chlorophyll $a$ was de- 


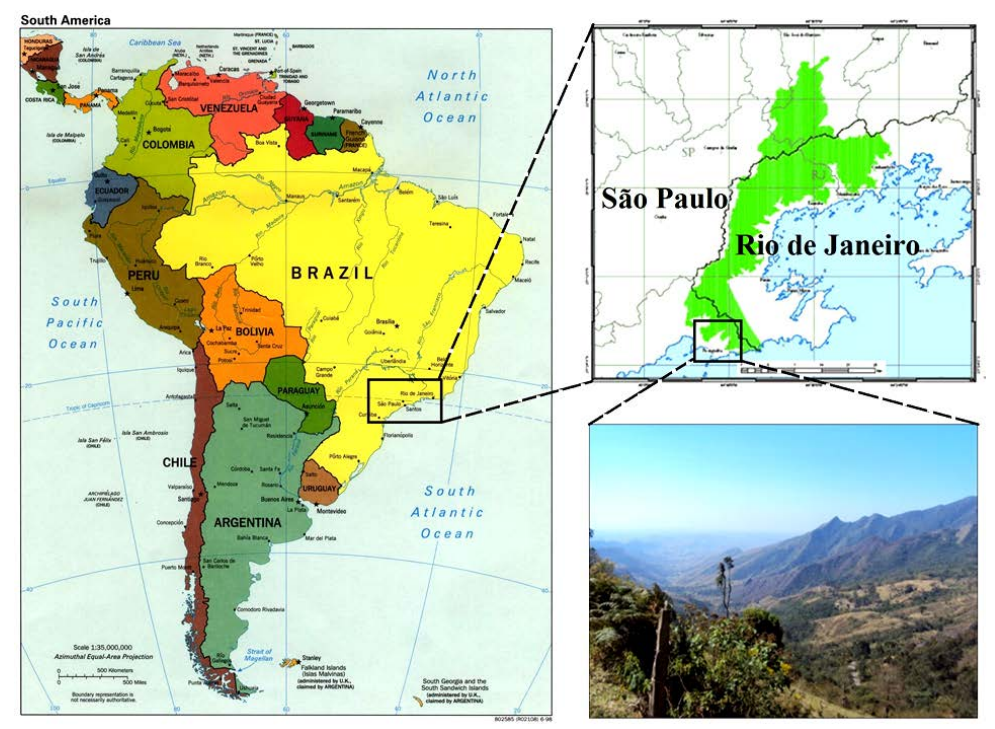

https://encrypted-tbn3.gstatic.com/images?q=tbn:ANd9GcQuPYLmFf-

GHnkx28OeseDXmV1OuwVzS9JVpf8UTT2TPBG186TC (Accessed on February 17, 2014)

Figure 1. Map of South America (Brazil) highlighting the location of the trout farming system.

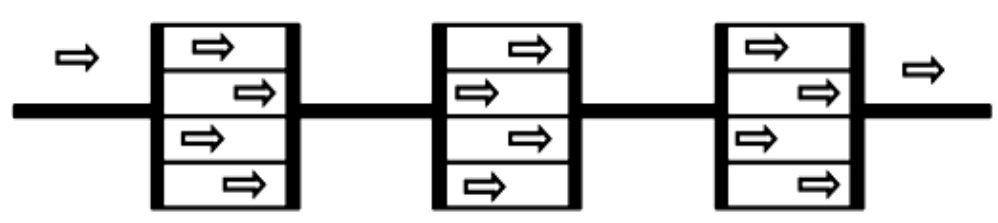

Fingerlings sector Juveniles sector Fattening sector

Figure 2. Representation of the trout farming system on Serra da Bocaina (SP), organized into three sectors: fingerlings, juveniles and fattening, where each sector is divided into four tanks. Arrows = flow of water supply to the tanks. Black bar = channel supply.

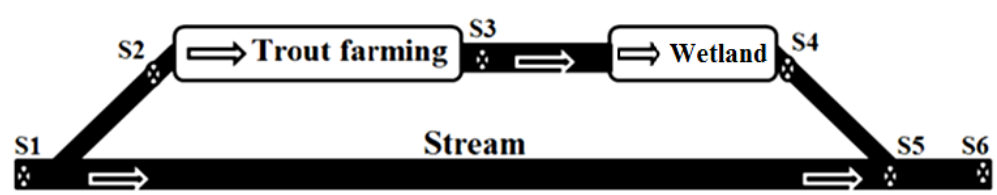

Figure 3. Representation of sampling sites of the study place on Serra da Bocaina-São Paulo, where: S1-upstream from trout farming system; S2-water supply; S3 - effluent; S4-artificial wetland; S5-mixing zone and S6dowstream (60 meters from the effluent); arrows = flow of water through the trout farming system and returning to the river that supplies the production.

termined according to the method described by Sartory and Grobellar [19].

The flow rate was calculated from the product of the channel section and average water velocity, measured by the float method [20]. The discharges of effluent released were determined by the product between water flow and the nutrient concentration.

\subsection{Statistical Analysis}

In order to characterize the zootechnical cycle environmental parameters were described in terms of average value and confidence interval of $95 \%$. Site variations on the variables were analyzed through a Kruskal Wallis test after $\log (x+1)$ transformation, followed by a SNK test. The level of significance adopted was 0.05 [21]. 


\section{Results}

Spatio analysis showed different pattern among parameter analyzed. Significant variations among sites were found in conductivity $(\mathrm{H}=57.71 ; \mathrm{P}<0.001)$, dissolved oxygen $(\mathrm{H}=82.98 ; \mathrm{P}<0.001)$, water temperature $(\mathrm{H}=$ 14.20; $\mathrm{P}=0.014)$, total phosphorus $(\mathrm{H}=161.54$; $\mathrm{P}<0.001)$, total nitrogen $(\mathrm{H}=18.45 ; \mathrm{P}=0.002)$, orthophosphate $(\mathrm{H}=133.55 ; \mathrm{P}<0.001)$, ammonium $(\mathrm{H}=65.16 ; \mathrm{P}<0.001)$, nitrite $(\mathrm{H}=11.84 ; \mathrm{P}=0.037)$, chlorophyll $a$ $(\mathrm{H}=52.31 ; \mathrm{P}<0.001)$, total solids suspended $(\mathrm{H}=96.07 ; \mathrm{P}<0.001)$, TSS organic $(\mathrm{H}=45.38 ; \mathrm{P}<0.001)$ and TSS inorganic $(\mathrm{H}=81.03 ; \mathrm{P}<0.001)$ (Table 1$)$.

Considering the current legislation CONAMA resolution [22] (Class II, lotic environment) and compared to the usual monitoring water quality parameters for production, only total phosphorus demonstrated not acceptable value at S4 point. The turbidity values were below $10 \mathrm{NTU}$ at all sites and the nitrate values were below 0.10 $\mu \mathrm{g} / \mathrm{L}$.

The trout faming system exported $9.80 \mathrm{~kg}$ TP/month e $120.00 \mathrm{~kg}$ PT/year with discharge of $13.21 \mathrm{~g}$ TP/ $\mathrm{kg}$ of feed in a volume of feeding of $25.00 \mathrm{~kg} /$ day (Table 2).

Table 1. Average and confidence interval (95\%) of parameters analyzed during the study cycle of trout farming system. Means followed by the same letters in the line do not differ by SNK test (0.05).

\begin{tabular}{|c|c|c|c|c|c|c|c|}
\hline \multirow{2}{*}{ Parameters } & \multicolumn{6}{|c|}{ Sites } & \multirow{2}{*}{$\begin{array}{c}\text { Reference } \\
\text { Values }\end{array}$} \\
\hline & $\mathrm{S} 1$ & $\mathrm{~S} 2$ & S3 & S4 & S5 & S6 & \\
\hline $\mathrm{pH}$ & $6.97^{\mathrm{a}} \pm 0.37$ & $7.03^{\mathrm{a}} \pm 0.32$ & $6.75^{\mathrm{a}} \pm 0.41$ & $6.79^{\mathrm{a}} \pm 0.36$ & $6.84^{\mathrm{a}} \pm 0.35$ & $6.74^{\mathrm{a}} \pm 0.36$ & $6.00-9.00^{* *}$ \\
\hline $\begin{array}{c}\text { Cond } \\
(\mu \mathrm{S} / \mathrm{cm})\end{array}$ & $10.50^{\mathrm{a}} \pm 1.20$ & $12.18^{\mathrm{a}} \pm 4.26$ & $12.93^{\mathrm{b}} \pm 1.53$ & $11.75^{\mathrm{bc}} \pm 0.80$ & $11.82^{\mathrm{C}} \pm 1.11$ & $13.89^{c} \pm 5.68$ & $20-500^{* *}$ \\
\hline \% DO Sat & $125.89^{\mathrm{a}} \pm 9.16$ & $122.80^{\mathrm{a}} \pm 7.82$ & $106.73^{\mathrm{b}} \pm 5.39$ & $108.26^{\mathrm{b}} \pm 6.40$ & $106.16^{\mathrm{b}} \pm 5.05$ & $109.53^{b} \pm 6.13$ & $\geq 80.00^{* *}$ \\
\hline $\mathrm{T}\left({ }^{\circ} \mathrm{C}\right)$ & $16.64^{\mathrm{a}} \pm 0.96$ & $16.80^{\mathrm{a}} \pm 0.85$ & $17.60^{\mathrm{bc}} \pm 0.93$ & $17.71^{\text {bc }} \pm 0.82$ & $17.37^{\mathrm{ac}} \pm 0.84$ & $17.24^{\mathrm{ac}} \pm 0.87$ & $\leq 20.00^{* *}$ \\
\hline $\mathrm{TP}(\mu \mathrm{g} / \mathrm{L})$ & $70.23^{\mathrm{a}} \pm 3.31$ & $72.43^{\mathrm{a}} \pm 4.00$ & $99.69^{\mathrm{b}} \pm 5.01$ & $100.63^{\mathrm{b}} \pm 8.74$ & $87.05^{\mathrm{c}} \pm 4.67$ & $87.80^{c} \pm 3.99$ & $\leq 100.00^{*}$ \\
\hline $\begin{array}{c}\mathrm{TN} \\
(\mu \mathrm{g} / \mathrm{L})\end{array}$ & $557.93^{\mathrm{a}} \pm 193.65$ & $514.36^{\mathrm{a}} \pm 128.23$ & $634.29^{c} \pm 147.85$ & $656.71^{\mathrm{c}} \pm 180.21$ & $500.67^{\mathrm{a}} \pm 123.94$ & $442.93^{\mathrm{a}} \pm 104.83$ & $\leq 2180^{*}$ \\
\hline $\begin{array}{l}\mathrm{P}-\mathrm{PO}_{4} \\
(\mu \mathrm{g} / \mathrm{L})\end{array}$ & $71.59^{\mathrm{a}} \pm 2.96$ & $69.20^{\mathrm{a}} \pm 2.60$ & $88.04^{b} \pm 6.25$ & $90.70^{\mathrm{b}} \pm 4.62$ & $85.72^{b} \pm 4.11$ & $85.84^{b} \pm 4.78$ & - \\
\hline $\begin{array}{l}\text { N-NH } 4 \\
(\mu \mathrm{g} / \mathrm{L})\end{array}$ & $110.18^{\mathrm{a}} \pm 33.38$ & $106.34^{\mathrm{a}} \pm 32.83$ & $217.32^{\mathrm{b}} \pm 60.70$ & $215.41^{b} \pm 52.11$ & $188.15^{\mathrm{b}} \pm 49.18$ & $179.32^{\mathrm{b}} \pm 40.42$ & $\begin{array}{c}\leq 3700 \text { if } \mathrm{pH} \\
\leq 7.50^{*}\end{array}$ \\
\hline $\begin{array}{l}\mathrm{N}-\mathrm{NO}_{2} \\
(\mu \mathrm{g} / \mathrm{L})\end{array}$ & $0.53^{\mathrm{a}} \pm 0.27$ & $0.23^{\mathrm{b}} \pm 0.17$ & $0.58^{\mathrm{ab}} \pm 0.45$ & $0.73^{\mathrm{ab}} \pm 0.60$ & $0.50^{\mathrm{a}} \pm 0.32$ & $0.65^{\mathrm{a}} \pm 0.41$ & $\leq 1000^{*}$ \\
\hline $\begin{array}{c}\text { TSS } \\
(\mathrm{mg} / \mathrm{L})\end{array}$ & $0.51^{\mathrm{a}} \pm 0.28$ & $0.49^{\mathrm{a}} \pm 0.21$ & $1.58^{\mathrm{b}} \pm 0.61$ & $1.57^{\mathrm{bc}} \pm 0.58$ & $1.07^{\mathrm{cd}} \pm 0.36$ & $0.88^{\mathrm{d}} \pm 0.30$ & - \\
\hline $\begin{array}{l}\text { TSS org } \\
(\mathrm{mg} / \mathrm{L})\end{array}$ & $0.25^{\mathrm{a}} \pm 0.19$ & $0.23^{\mathrm{a}} \pm 0.15$ & $0.46^{\mathrm{b}} \pm 0.16$ & $0.67^{\mathrm{b}} \pm 0.36$ & $0.50^{\mathrm{b}} \pm 0.20$ & $0.41^{\mathrm{b}} \pm 0.20$ & - \\
\hline $\begin{array}{c}\text { TSS inorg } \\
(\mathrm{mg} / \mathrm{L})\end{array}$ & $0.26^{\mathrm{a}} \pm 0.10$ & $0.25^{\mathrm{a}} \pm 0.07$ & $1.12^{\mathrm{b}} \pm 0.50$ & $0.90^{\mathrm{bc}} \pm 0.33$ & $0.57^{\mathrm{cd}} \pm 0.21$ & $0.47^{\mathrm{d}} \pm 0.14$ & - \\
\hline $\begin{array}{c}\text { CHL } \\
(\mu \mathrm{g} / \mathrm{L})\end{array}$ & $0.18^{\mathrm{a}} \pm 0.07$ & $0.28^{\mathrm{a}} \pm 0.17$ & $0.61^{b} \pm 0.18$ & $0.41^{\mathrm{bc}} \pm 0.10$ & $0.38^{\mathrm{C}} \pm 0.11$ & $0.51^{\mathrm{bc}} \pm 0.16$ & $\leq 30.00^{*}$ \\
\hline
\end{tabular}

Cond = Conductivity; \% DO Sat = percentage of dissolved oxygen saturation; $\mathrm{T}=$ water temperature; $\mathrm{TP}=$ total phosphorus; $\mathrm{TN}=$ total nitrogen; $\mathrm{P}-\mathrm{PO}_{4}=$ orthophosphate; $\mathrm{N}-\mathrm{NH}_{4}=$ ammonium; $\mathrm{N}-\mathrm{NO}_{2}=$ nitrite; $\mathrm{N}-\mathrm{NO}_{3}=$ nitrate; $\mathrm{CHL}=$ chlorophyll $a$; TSS = total suspended solids; $\mathrm{TSS}$ org = organic fraction of total suspended solids; TSS inorg = inorganic fraction of total suspended solids; ${ }^{*}[22] ;{ }^{* *}[23]$.

Table 2. Description of the values of water flow (L/s), production (t/year), feeding ( $t /$ year), phosphorus export coefficient (PET) depending on the amount of feed (g PT/Kg of feed) and feed conversion rate (FCR) found by others studies and by this study.

\begin{tabular}{ccccccc}
\hline Water flow (L/s) & Production (t/year) & Feed (t/year) & PET (g PT/Kg of feed) & FCR & Authors \\
\hline 1762 & 40.00 & 50.00 & 9.66 & 6.57 & 1.50 & 0.95 \\
1762 & 60.00 & 67.00 & 10.13 & {$[7]$} & 1.20 \\
190.00 & $15.00-25.00$ & 27.00 & 750.00 & 9.70 & 1.07 \\
2000 & 700.00 & 9.12 & 13.21 & {$[24]$} & 2.12 & Present study \\
40.00 & 3.50 & &
\end{tabular}




\section{Discussion}

The results presented here constitute the first contribution to trout farming systems in tropical and subtropical regions. Despite the system analyzed is considered small, due to the water flow, it represents $70 \%$ of Brazilian trout farming systems, where production is up to $20 \mathrm{t}$ /year due to water availability [26].

The abiotic factors described in the monitoring water quality such $\mathrm{pH}$, conductivity, dissolved oxygen, water temperature and turbidity demonstrated acceptable values for trout production. The $\mathrm{pH}$ remained slightly acid, favorable condition to the welfare of trout, because when in alkaline $\mathrm{pH}$, ammonia excreted by the fish becomes more toxic. The conductivity values lower than $39 \mu \mathrm{S} / \mathrm{cm}$ indicate low rate of decomposition of organic matter related to the low residence time of water in the production system. During the production cycle, the water remained well oxygenated with more than $100 \%$ of oxygen saturation values. The minimum limit for percentage of oxygen saturation recommended for trout is $80 \%$ [23]. The water temperature remained at acceptable values for the best growth of the animals, not exceeding $18.63^{\circ} \mathrm{C}$, value within the classification of highland tropical climate $\left(10^{\circ} \mathrm{C}-22^{\circ} \mathrm{C}\right)[1]$. Regarding the turbidity, low values were obtained $(<10 \mathrm{NTU})$.

The impact of intensive trout farming on a river depends on the size of the farm, the farming practices, the nature and volume of the wastes produced [10]. In Brazil, in 2010, from the 264,000 tons of feed were produced for aquaculture, $80.4 \%$ went to feed fish [27] [28]. Many industries have produced low quality rations to be marketed at lower prices. This fact leads to the use of diets of low digestibility [29]. This situation results in the deterioration of water quality due to excessive excretion of nutrients coming from fish and remains of feed.

Environmentally, changes have occurred in the parameters related to the eutrophication process. After passing through the production system (S3 and S4) it is possible to observe that there was an increase in concentrations of nutrients, with significant differences for TP, TN, $\mathrm{P}-\mathrm{PO}_{4}, \mathrm{~N}-\mathrm{NH}_{4}, \mathrm{CHL}$, TSS and their organic and inorganic fractions. High feeding rates increase the output of organic matter from farms either as uneaten feed or faeces [30]. At the S5 and S6 sites there was a reduction in concentrations when compared to the values of S3 and S4 due to the dilution process of the receiving water body.

The increases in the concentrations of TP and TN attributed to the feeding and metabolism of organisms were due to use of low quality feed and corroborated by the conversion rate considered inadequate (2.12). Other studies in intensive system of production of trout, with higher water flow, production and use of feed showed values of feed conversion ratio closer to 1:1, indicating better management, fact which caused minor discharge of phosphorus compared to the present study [7] [24] [25]. The higher phosphorus loads on trout farming investigated in this study seemed to be associated with the high phosphorus content of feeds used and insufficient feed management.

In countries where strict environmental regulations govern the operation of trout farms, phosphorus content of trout feed and FCR are not permitted to exceed $0.9 \%-1.0 \%$ and 1.0, respectively [31] [32]. In Brazil, there is no legislation that deals with the content of phosphorus in the feed composition for the purpose of reducing environmental impact. Brazilian legislation regulates only the limits of allowable concentrations of phosphorus in the effluent to be discharged in accordance with framing of the water body (Table 1).

Despite to the orthophosphate, when the percentage of $\mathrm{P}_{-} \mathrm{PO}_{4}$ in relation to TP is $<10 \%$ indicates an accumulation of $\mathrm{P}$ in phytoplankton and debris [33]. In this study, the percentage of $\mathrm{P}^{-\mathrm{PO}_{4}}$ relative to $\mathrm{TP}$ was $>90 \%$ indicating that this element was exported directly in effluent. Average concentrations after passage by trout farming (Site 3) showed no decrease in the mixing zone (Site 5) and downstream (Site 6) (P > 0.05), demonstrating that the distance of $60 \mathrm{~m}$ was insufficient to observe the activity of resilience on the receiving water body.

The increase of $\mathrm{N}-\mathrm{NH}_{4}$ is clearly related to feeding and excretion of the fish. The mean concentration of $\mathrm{N}-\mathrm{NH}_{4}$ in effluent of the trout farming system $(217.32 \mu \mathrm{g} / \mathrm{L})$ increased by $104 \%$ from water supply (106.34 $\mu \mathrm{g} / \mathrm{L}$ ). However, the $\mathrm{N}_{-} \mathrm{NH}_{4}$ concentration do not exceeded the recommended limit for effluents [22]. The mean concentration of $\mathrm{N}^{-\mathrm{NO}_{2}}$ in effluent of the trout farming system $(0.58 \mu \mathrm{g} / \mathrm{L})$ increased by $152 \%$ from water supply $(0.23 \mu \mathrm{g} / \mathrm{L})$ and the $\mathrm{N}-\mathrm{NO}_{2}$ concentration in effluent do not exceeded the recommended limit for effluent [22], dynamic similar to the $\mathrm{N}-\mathrm{NH}_{4}$. The mean concentration of TSS and their organic and inorganic fractions in effluent of the trout farming system $(1.58 ; 0.46 ; 1.12 \mathrm{mg} / \mathrm{L}$ ) increased by $222 \%, 100 \%$ and $348 \%$ from water supply $(0.49 ; 0.23,0.25 \mathrm{mg} / \mathrm{L})$, respectively.

Most studies on evaluation of total suspended solids do not describe their inorganic and organic fractions [34]. Due to their contribution in nutrient input, the estimated concentration of total solids in suspension (TSS) coming from of production system may be an appropriate variable for evaluating the effluent from a fish farming. In 
farming systems with good management practices, the main source of suspended material originates from the fish feces [35]. Therefore, in this study, the results can be associated with feeding practices, such as frequency, stocking density, quality and amount of feed that interfere in excretion rates.

The constant renewal of water in the trout farming hindered the establishment of phytoplankton, indicated by the low values of chlorophyll $a$.

After passing through the artificial wetland there was an increase in the concentration of TP, TN, P-PO $\mathrm{N}-\mathrm{NO}_{2}$ and organic TSS. Although not statistically significant, indicates that the wetland is not efficient. Among the different aspects for improving this treatment system must consider the proportional dimension of wetland to the production.

\section{Conclusion}

Finally, long-term sustainability of many fish farms may be dependent on their ability to reduce their waste outputs. Therefore, it is necessary to use best quality feed to meet the nutritional requirements of trout, maintaining an optimal feed conversion and reducing pollution generated by effluent.

\section{Acknowledgements}

We thank FAPESP for financial support (Process 2010/07658-3) and Marcos Guilherme Rigolino from Experimental Station of Salmon in memoriam.

\section{References}

[1] Virtual Library of São Paulo State (2007) Geography of São Paulo State. (in Portuguese) http://www.bibliotecavirtual.sp.gov.br/pdf/saopaulo-geografia.pdf

[2] Tabata, Y.A. (2008) Applied Biotechnologies to Trout Farming System. Revista Colombiana de Ciencias Pecuarias, 21, 455-522. (in Portuguese)

[3] Ministry of Fisheries and Aquaculture (2012) Fisheries and Aquaculture Statistical Bulletin-Brazil 2010. (in Portuguese) http://www.mpa.gov.br/images/Docs/Informacoes_e_Estatisticas/Boletim\%20Estat\%C3\%ADstico\%20MPA\%202010. pdf

[4] Sindilariu, P.D., Brinker, A. and Reiter, R. (2009) Factors Influencing the Efficiency of Constructed Wetlands Used for the Treatment of Intensive Trout Farm Effluent. Ecological Engineering, 35, 711-722. http://dx.doi.org/10.1016/j.ecoleng.2008.11.007

[5] Amirkolaie, A.K. (2011) Reduction in the Environmental Impact of Waste Discharge by Fish Farms through Feed and Feeding. Reviews in Aquaculture, 3, 19-26. http://dx.doi.org/10.1111/j.1753-5131.2010.01040.x

[6] Noroozrajabi, A., Ghorbani, R., Abdi, O. and Nabavi, E. (2013) The Impact of Rainbow Trout Farm Effluents on Water Physicochemical Properties of Daryasar Stream. World Journal of Fish and Marine Sciences, 5, 342-346. http://dx.doi.org/10.5829/idosi.wjfms.2013.05.03.72175

[7] Pulatsu, S., Rad, F., Köksal, G., Aydin, F., Benli, A.C.K. and Topçu, A. (2004) The Impact of Rainbow Trout Farm Effluents on Water Quality of Karasu Stream, Turkey.Turkish Journal of Fisheries and Aquatic Sciences, 4, 9-15.

[8] Teixeira, E.A., Crepaldi, D.V., Faria, P.M.C., Ribeiro, L.P., Melo, D.C., Euler, A.C.C. and Saliba, E.O.S. (2006) Replacement of Fishmeal in Feeds for Fish. Revista Brasileira de Reprodução Animal, 30, 118-125. (in Portuguese)

[9] Piedrahita, R.H. (2003) Reducing the Potential Environmental Impact of Tank Aquaculture Effluents through Intensification and Recirculation. Aquaculture, 226, 35-44. http://dx.doi.org/10.1016/S0044-8486(03)00465-4

[10] Boaventura, R., Pedro, A.M., Coimbra, J. and Lencastre, E. (1997) Trout Farm Effluents: Characterization and Impact on the Receiving Streams.Environmental Pollution, 95, 379-387. http://dx.doi.org/10.1016/S0269-7491(96)00117-0

[11] Cao, L., Wang, W., Yang, Y., Yang, C., Yuan, Z., Xiong, S. and Diana, J. (2007) Environmental Impact of Aquaculture and Countermeasures to Aquaculture Pollution in China.Environmental Science and Pollution Research, 14, 452462. http://dx.doi.org/10.1065/espr2007.05.426

[12] Koçer, M.A.T., Kanyilmaz, M., Yilayaz, A. and Sevgili, H. (2013) Waste Loading Into a Regulated Stream from Land-Based Trout Farms. Aquaculture Environment Interactions, 3, 187-195. http://dx.doi.org/10.3354/aei00059

[13] Yalcuk, A., Pakdil, N.B. and Kantürer, O. (2014) Investigation of the Effects of Fish Farms in Bolu (Turkey) on Aquatic Pollution. International Journal of Agricultural and Food Research, 3, 1-13.

[14] Valderrama, J.C. (1981) The Simultaneous Analysis of Total Nitrogen and Total Phosphorus in Natural Waters. Marine Chemistry, 10, 109-122. http://dx.doi.org/10.1016/0304-4203(81)90027-x 
[15] Strickland, J.D. and Parsons, T.R. (1960) A Manual of Seawater Analysis. Bulletin of the Fisheries Research Board of Canada, 125, 1-185.

[16] APHA, AWWA and WPCF (2005) Standard Methods for the Examination of Water and Wastewater. 21st Edition, American Public Health Association, American Water Works Association and Water Pollution Control Federation, Washington DC.

[17] Teixeira, C., Tundisi, J. and Kutner, M.B. (1965) Plankton Studies in a Mangrove Environment II: The Standing-Stock and some Ecological Factors. Boletim do Instituto Oceanográfico, 14, 13-41. http://dx.doi.org/10.1590/S0373-55241965000100002

[18] Wetzel, R.G. and Likens, G.E. (1991) Limnological Analysis. 2nd Edition, Springer Verlag, New York.

[19] Sartory, D.P. and Grobbelaar, J.U. (1984) Extraction of Chlorophyll $a$ from Freshwater Phytoplankton for Spectrophotometric Analysis. Hydrobiologia, 114, 177-187. http://dx.doi.org/10.1007/BF00031869

[20] Marques, V.S. and Argento, M.S.F. (1988) The Use of Floats for Assessment of Flow of River Channels. Geociência, 7, 173-186. (in Portuguese)

[21] Zar, J.H. (2010) Biostatistical Analysis. 5th Edition, Pearson Prentice Hall, New Jersey.

[22] Brazil (2005) CONAMA Resolution No. 357 of March of 2005. Official Gazette of the Federative Republic of Brazil, Brasília. (in Portuguese) http://www.mma.gov.br/port/conama/res/res05/res35705.pdf

[23] Sabaut, J.J. (1976) Raising of Rainbow Trout. CIPASA, Fish Food, Spain, 24 p. (in Spanish)

[24] Bartoli, M., Nizzoli, D., Longhi, D., Laini, A. and Viaroli, P. (2007) Impact of a Trout Farm on the Water Quality of an Apennine Creek from Daily Budgets of Nutrients.Chemistry and Ecology, 23, 1-11. http://dx.doi.org/10.1080/02757540601084003

[25] Tekinay, A.A., Güroy, D. and Çevik, N. (2009) The Environmental Effect of a Land-Based Trout Farm on Yuvarlakçay, Turkey. Ekoloji, 73, 65-70.

[26] Amaral, G.F. (2007) Analysis of Trout Segment: Approaches to Supply Chain and Rural Tourism. Master Thesis, Federal Rural University of Rio de Janeiro, Rio de Janeiro. (in Portuguese)

[27] Union of Industries of Animal Nutrition (2011) (in Portuguese) http://sindiracoes.org.br/wp-content/uploads/2012/05/sindiracoes boletim-informativo-versao-portugues-atual-maio20 12.pdf

[28] Ayroza, L.M.S. and Ayroza, D.M.M.R. (2012) Perspective of the Fishery in São Paulo State. Pesquisa e Tecnologia, 9, 2, 1-6. (in Portuguese)

[29] Abimorad, E.G., Gonçalves, G.S. and Castellani, D. (2012) The Food Crisis and Reflection in Brazilian Aquaculture. Pesquisa e Tecnologia, 9, 1-4. (in Portuguese)

[30] Miller, D. and Semmens, K. (2002) Waste Management in Aquaculture. West Virginia University, Publication No.. AQ02-1. http://aquaculture.ext.wvu.edu/r/download/43721

[31] Bergheim, A. and Cripps, S.J. (1998) Effluent Management: Overview of the European Experience. Proceedings of the 2nd International Conference on Recirculating Aquaculture, Roanoke, 16-19 July 1998, 233-244.

[32] MacMillan, J.R., Huddleston, T., Woolley, M. and Forthergill, K. (2003) Best Management Practice Development to Minimize Environmental Impact from Large Flow through Trout Farms. Aquaculture, 296, 91-99. http://dx.doi.org/10.1016/S0044-8486(03)00470-8

[33] Poxton, M.G. (1990) A Review of Water Quality for Intensive Fish Culture. Aquaculture Society, 12, 285-303.

[34] Dalsgaard, J. and Pedersen, P.B. (2011) Solid and Suspended/Dissolved Waste (N, P, O) from Rainbow Trout (Oncorhynchus mykiss). Aquaculture, 313, 92-99. http://dx.doi.org/10.1016/j.aquaculture.2011.01.037

[35] Brinker, A., Koppe, W. and Rösch, R. (2005) Optimizing Trout Farm Effluent Treatment by Stabilizing Trout Feces: A Field Trial. North American Journal of Aquaculture, 67, 244-258. http://dx.doi.org/10.1577/A04-078.1 
Scientific Research Publishing (SCIRP) is one of the largest Open Access journal publishers. It is currently publishing more than 200 open access, online, peer-reviewed journals covering a wide range of academic disciplines. SCIRP serves the worldwide academic communities and contributes to the progress and application of science with its publication.

Other selected journals from SCIRP are listed as below. Submit your manuscript to us via either submit@scirp.org or Online Submission Portal.
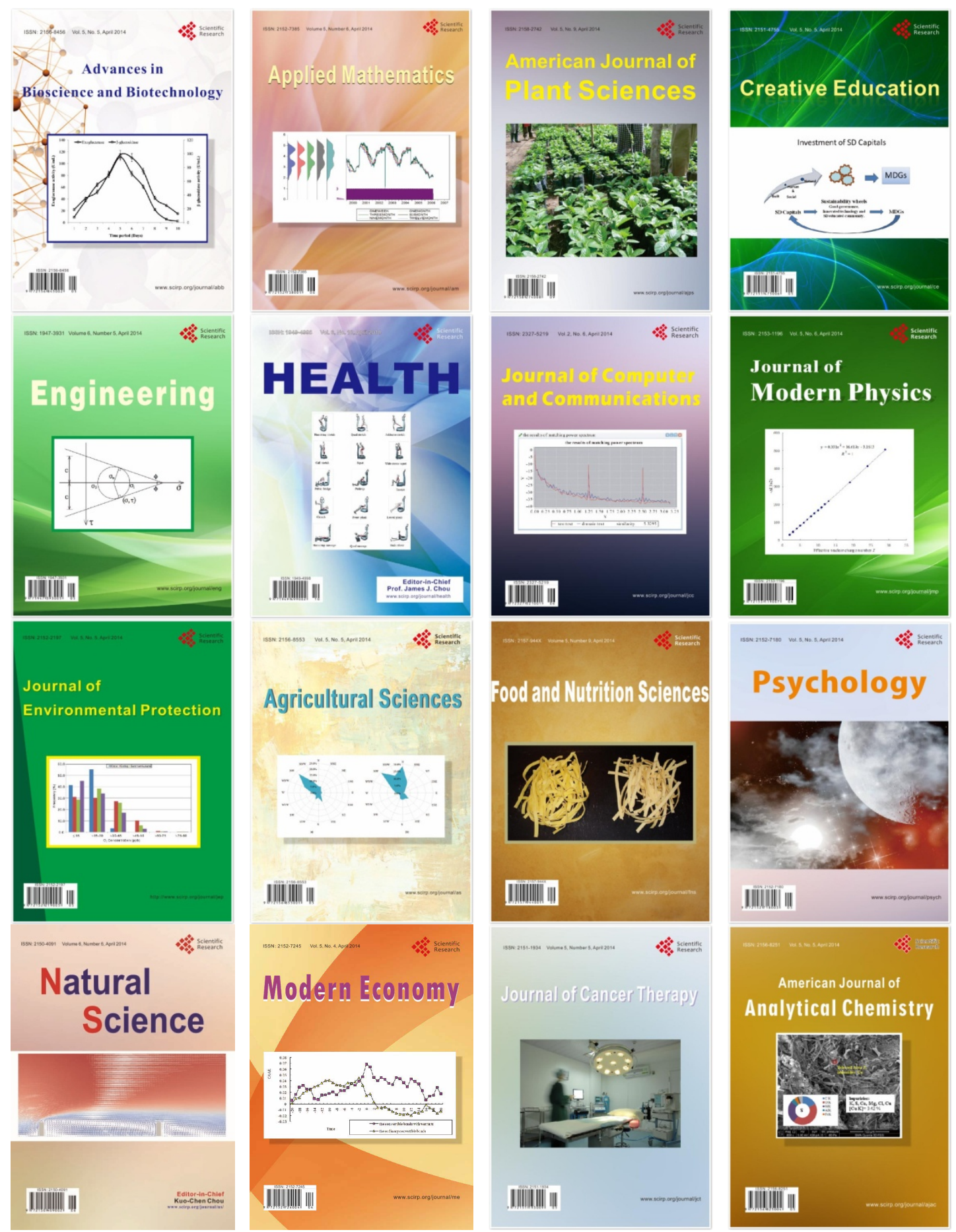